\title{
Mystery Shopping - a Tool for Sales Processes Evaluation in the Hospitality Facilities
}

\author{
L’ubica Šebová ${ }^{1}$, Radka Marčeková1 $^{1}$, Radim Dušek ${ }^{2}$ \\ ${ }^{1}$ Faculty of Economics, Matej Bel University in Banská Bystrica, Slovakia \\ 2Institute of Technology and Business in České Budějovice, Faculty of Corporate \\ Strategy, Department of Tourism and Marketing, Czech Republic
}

\begin{abstract}
Mystery shopping can be characterized as a marketing method used for anonymous and objective evaluation of the quality of provided services. The method helps the owner of the company, where the mystery shopping is applied, to gain better images of processes in the company, information about employee behavior towards customers, quality of provided services, environment, atmosphere, etc. It is realized by mystery shoppers who give the owner the information about used services gained by secret purchases. The aim of the paper is to examine the use of the mystery shopping method as a tool for evaluating the sales process in hospitality facilities. We research the use of mystery shopping from two points of view. On one hand, based on the structured interviews with managers of mystery shopping agencies and, on the other hand, based on structured interviews with managers of hospitality facilities that use mystery shopping method. All researched companies agreed on the statement that mystery shopping is very good primary impulse for changes in the company but has to be followed by training and to achieve success and guests' satisfaction devoted work of the management and all its employees is necessary.
\end{abstract}

Keywords: hospitality facility, mystery shopping, process, sales

\section{Introduction}

Mystery shopping is a one of the marketing methods, which serves for anonymous and fair evaluation of customer services and services quality by an external trained expert so- 
called a mystery shopper who plays the role of a customer, but his task is to evaluate provided services. Mystery shopping is very well-known abroad, while in Slovakia it is no so much known or used. Mystery shopping is carried out in companies which provide services. As tourism and hospitality companies are providing services to their customers, mystery shopping has a very good exploitation right in these companies. Only few companies use the method and there are still many of them that have not yet heard about the method. But the companies which take advantage of using the method are rewarded by satisfied customers, higher quality level of services and professional behaved employees. Especially in tourism, where there are high requests on the quality of provided services and we expect from the satisfied customer, that he becomes loyal, the mystery shopping is very suitable method to be used to evaluate the sales processes. The method helps the owner to gain better images of processes in the company, employee behavior towards customers, quality of provided services, environment, atmosphere, etc. It is realized by mystery shoppers who give the owner the information about used services gained by secret purchases. The owner has the information which can help him to find out the exact problems by services providing and he can make the adjustments to improve the situation. In tourism, mystery shopping is realized in hospitality facilities, accommodation facilities, travel agencies and in other tourism companies.

Mystery shopping can be characterized "as a marketing method used for anonymous and objective evaluation of the quality of provided services and customer service" (www.toptest.sk). Baarová (2008) classifies mystery shopping among evaluation methods that deal with the study of human behavior in the society. The professional critic is usually an external, professionally trained evaluator, the so-called mystery shopper. The author further states that the method is most often applied in the field of sales and services evaluation. In examining both characteristics, it is clear that the method is used to improve the services provided to customers, it is a picture of the state of the company in terms of its employees' behavior, also serves as an impulse for corrective and preventive measures to improve customer service, retain regular customers and create the conditions for gaining new customers.

Several domestic and foreign authors (Baarová, 2008; Jankal and Jankalová, 2011; Ďad'o and Petrovičová, 2013; Moravčíková, 2014, Minghetti and Celotto, 2014; Chen and Barrows, 2015) understand mystery shopping as a form of secret visits, during which the agent, a specialist called mystery shopper pretends to be a regular customer, being a trained worker who knows exactly how to behave in the chosen environment. After visiting the company, he fills out a test form. Based on regularly repeated specialized tests and their continuous evaluation the aim is to significantly increase the level of the services. The client himself determines which aspects will be monitored. It is necessary to set the concept of mystery shopping and tasks while performing mystery shopping. The main goal is to bring the management of the facility in which mystery shopping is being performed an objective and true picture of the company from the point of view of a regular customer. 
Mystery shopping is a marketing research tool. Ďad'o and Petrovičová (2013) define marketing research "as the systematic identification, collection, analysis and evaluation of information related to a particular problem the company is facing". Mystery shopping is a similar method to marketing research, but it does not fully correspond to its content. The term mystery shopping means research that is used to evaluate customer services, it is a method to improve the quality of services and customers' satisfaction with the use of the services. The method involves direct interaction between the seller and the user of the services, who tries to evaluate the quality of the services provided in a professional and secret way. The purpose is to analyze the strengths and weaknesses of the services offered, which are aimed at evaluating not only the seller's approach to the customer, but also the overall appearance of the company and employees. It allows the company to obtain information on the level of sales, qualification and behavior of employees who provide services. It is an independent feedback from the customer's point of view (Moravčíková, 2014).

Customer satisfaction helps to build his loyalty, which is essential especially in tourism, so when researching, we have to monitor the way of providing services before, during and after purchasing the service. The result should be a satisfied customer who does not pass on to the competition but happily returns to the company and becomes loyal.

We most often encounter the following forms of mystery shopping (Chen and Barrows, 2015). Mystery shopping, which measures the behavior of employees during a personal conversation with a customer. It is performed by trained staff who focus on the employee's behavior during the services providing. The examined criteria include e.g. standards of accepting clients, identification of their needs, qualification and level of services and information provided, willingness of employees, handling criticism and attacks from clients, etc. After the end of the mystery shopping, the mystery shopper processes the evaluation sheet or form and then the overall final report from all visits is processed (www.perman.sk). Mystery calling deals with the behavior of the employees during a telephone conversation. It is performed by trained employees who evaluate the required aspects of the employee's behavior, such as telephone answering standards, willingness to provide information, professional and communication level of employees, handling criticism and attacks from the customer. Same as with mystery shopping, an evaluation sheet (form) and an overall final report are processed. Mystery e-mailing measures the response of employees to a customer's e-mail inquiry. It is performed by trained staff who evaluate individual aspects of communication via e-mail and compliance with standards by the responsible employee. It is completed with an elaborated evaluation sheet (form) and an overall final report.

Mystery visit is focused on evaluating customer service in the stores and facilities and evaluation of the facility as a whole. The material and technical equipment of the store or facility, posters, appearance and behavior of sellers, the ability to provide information, consulting skills, compliance with processes and standards, length of service are monitored. Another form of mystery shopping is service mystery shopping, which measures the reaction of employees by handling customer complaints. The speed and 
method of resolving complaints and returns of goods, the method of contact with the customer and finding out his other needs, or the offer of products with added value by employees are monitored. There is no direct contact with the staff during the mystery audit. The equipment of the store with promotional materials, current leaflets and readiness for the marketing campaign are monitored. Mystery flying is used to evaluate the employees on the board. The method of serving customers on the plane, the employee's attitude to the passengers, and the provision of relevant information is monitored. Mystery delivery focuses on compliance with standards in the field of parcel delivery. The speed of delivery, the control of the customer's identity, the integrity of the shipment, the approach, the friendliness of the courier are monitored, as well as the method of handing over the shipment. The goal of mystery clicks is to track internet sales. It examines communication with the employee, the availability of services, the willingness of the employee. Customer journey mystery shopping focuses on examining and evaluating the quality of services from the purchase of goods or services by customers, its use, service to the cancellation or termination of the service or goods. Another form of mystery shopping is mystery shopping with a real customer. It is used if the mystery shopper cannot simulate the role of the customer, therefore it comes into operation together with a real customer who requires a specific service, for example to set up an account at a bank. B2B mystery shopping and Competitive Intelligence mystery shopping focus on examining the quality of services provided for corporate clients in the business environment (Parobok, 2015).

The main factor in the exploitation of the mystery shopping method is the direct contact between the customer and the employee, through a service provided in person. One of the implementation criteria is the size of the company. It is mostly applied in the larger companies, because it is usually more financially demanding matter. Usually small businesses cannot afford evaluation using mystery shopping and are also unable to undertake the restructuring changes that result from the evaluation results (Ďad'o, 2013).

Mystery shopping is covered by the international association MSPA - Mystery shopping providers association, which brings together mystery shopping services providers. One of its main goals is to improve the overall quality within the mystery shopping industry and to create an open and transparent operational connection with clear rules (www.mspaeu.org). They require their members to adhere to ethical standards, honest, fair and professional conduct and thus participate on the good name of the mystery shopping method (Moravčíková, 2014).

\section{Methods and Data}

The aim of the paper is to examine the use of the mystery shopping method as a tool for evaluating the sales process in hospitality facilities.

Hospitality facilities provide catering services, which are a basic condition for the development of tourism. These services have a multifunctional character, as they are used not only by visitors in tourism but also by the local population. While in the past it was 
not typical to regularly consume in hospitality facilities, today they are becoming more and more used and, in addition to catering, they also fulfill a social function.

We researched the use of mystery shopping from two points of view. On one hand, based on the structured interviews with managers of mystery shopping agencies and, on the other hand, based on structured interviews with managers of hospitality facilities that use mystery shopping. When choosing mystery shopping agencies, we focused on those that offer the implementation of mystery shopping in hospitality facilities in Slovakia. We asked them questions to follow (table 1).

Tab. 1: Questions in structured interview with mystery shopping agencies

\begin{tabular}{|c|l|}
\hline Number & \\
\hline 1 & Question \\
\hline 2 & How would you characterize companies that use mystery shopping? \\
\hline 3 & How much on average are companies willing to spend on mystery shopping? \\
\hline 4 & How many times per year do the companies use mystery shopping? \\
\hline 5 & What is the most common mistake of hospitality staff made at work? \\
\hline 6 & What is the most common mistake of hospitality management at work? \\
\hline 7 & $\begin{array}{l}\text { Are employees and management willing to take advice to improve services and quality } \\
\text { that you offer them? }\end{array}$ \\
\hline 8 & What is the most common reason for not applying these advices? \\
\hline 9 & $\begin{array}{l}\text { Would you be able to advise hospital facilities how to improve the quality of the provided } \\
\text { services? }\end{array}$ \\
\hline 10 & $\begin{array}{l}\text { Where do you see the biggest problem in applying mystery shopping in the hospitality } \\
\text { facilities in Slovakia? }\end{array}$ \\
\hline 11 & How could mystery shopping agencies in Slovakia improve their services? \\
\hline
\end{tabular}

Source: Authors.

When researching the use of mystery shopping by hospitality facilities, we focused on facilities whose references we have found on the pages of mystery shopping agencies. We asked ten hospitality facilities for cooperation, three were willing to answer our questions (table 2).

Tab. 2: Questions in structured interview with mystery shopping agencies

\begin{tabular}{|l|l|}
\hline Number & \multicolumn{1}{c|}{ Question } \\
\hline 1 & What motivated you to use mystery shopping? \\
\hline 2 & How many times have you used mystery shopping? \\
\hline 3 & Has it brought an improvement to your company? \\
\hline 4 & If it has brought you an improvement, in what specifically? \\
\hline 5 & If it has not brought you an improvement, what was the cause? \\
\hline 6 & $\begin{array}{l}\text { How have employees reacted to the evaluation in the form of mystery shopping and the } \\
\text { introduction of novelties? }\end{array}$ \\
\hline 7 & Have you registered an increased number of customers or rise of their loyalty? \\
\hline 8 & Do you also use the trainings offered by mystery shopping agencies? \\
\hline 9 & How do you evaluate communication with a mystery shopping agency? \\
\hline 10 & $\begin{array}{l}\text { How do you perceive your experience and cooperation with the mystery shopping } \\
\text { agency? }\end{array}$ \\
\hline
\end{tabular}

Source: Authors. 
The work is based on data from primary and secondary sources. Primary data are obtained by the method of questioning through a standardized interview, secondary data are obtained from domestic and foreign journal (Sustainability, 2015), internet sources (www.expertz.sk, www.marketvision.sk, www.mspa-eu.org). Several methods of research are applied in the paper, using abstraction and generalization, comparison and analogy, induction and deduction.

The process of implementing the mystery shopping method runs in several phases (Jankal and Jankalová, 2011). Usually the whole process consists of three main phases, project preparation, research implementation and evaluation. In the first phase, the facility is aware of the need to implement mystery shopping, so it is looking for providers of this service. After the agreement with the mystery shopping agency on the price, specific requirements and conditions, a contract is signed. Futher the tasks are on the side of the mystery shopping agency by selecting mystery shoppers and training them. In this phase, the activities of the facility (client, company), the activities of the agency (mystery shopping agency) and their combination alternate. The second phase is the phase of mystery shopping itself and the completion of the evaluation form and questionnaires. An agency providing mystery shopping services is doing her job here, and the company expects results. The evaluation phase consists of the evaluation and analysis of questionnaires and evaluation forms, from which a final report is prepared, which is then presented to the company with comments and suggestions for improvement. The whole process ends with the awareness of the problems in the company and the implementation of corrective measures.

\section{Results and Discussion}

Compared to the past due to the influence of the internet and globalization the mystery shopping is becoming an increasingly well-known and popular tool for evaluating the quality of the company's services. There are several agencies in Slovakia that deal with this method of quality assessment, employees, processes, atmosphere, hospitality, etc. However, most agencies focus on a number of service sectors. Tourism in mystery shopping agencies often stands out as just one of the many industries that these agencies deal with. Therefore, the question arises whether the agencies with such a wide portfolio of industries evaluated are able to professionally evaluate the services provided in tourism.

\section{Characteristics of selected companies providing mystery shopping services in hospitality facilities}

In the following section, we will analyze agencies that offer mystery shopping services in tourism in Slovakia. For the needs of our paper, we will engage in mystery shopping in hospitality facilities and establishments. In this form of mystery shopping, the company focuses on restaurants, bars, cafes, or other forms of catering and refreshments for clients. According to their offer we have selected five agencies, namely Tales \& tails, eXpertz ltd., 
MysteryMan, COMTESSA Consulting ltd. and Market vision. These mystery shopping agencies are not only specified on hospitality facilities, their portfolio is wider.

The Tales \& tails project is relatively new on the tourism market. After many years of experience abroad, the successful launch and operation of his own cocktail bar, owner decided to move his knowledge and skills further. The project, as the owner calls it, focuses on three components: bartending school, mystery shopping and catering. Mystery shopping focuses exclusively on hospitality facilities. However, in the understanding of the owner, the evaluation through mystery shopping is not only focused on checking and sending feedback, but especially on the verification of operation, evaluation and correction of mistakes. They adapt the services to the client's requirements, evaluate everything according to the client requests, from the supplier to the menu. They provide mystery shopping all over Slovakia. The price of mystery shopping depends on the required service (www.talesandtails.sk).

Agency eXpertz ltd. has been operating on the mystery shopping market for more than 5 years. Its owners, after previous foreign experience, help to improve the quality of services provided in tourism in Slovakia. Their motto is "eXpertz - a company operating in tourism and for tourism" (www.expertz.sk). They train their mystery shoppers to come into company well prepared and thus provide real information about the company. Clients who order the service are not only considered as the customers, but they approach them as their partners.

It's easy to invite your friends to the facility to evaluate the operation, secretly check employees, but friends are likely to evaluate the operation unprofessionally, not paying attention to details. However, the company offers an objective view of experienced evaluators, fast and transparent negotiations, services tailored to the client's requirements and compile a comprehensive program to increase employee and management performance and improve the overall quality of hospitality facility.

In addition to evaluating the tourism company through mystery shopping, the young dynamic team also offers trainings and a training program for employees. The training program is tailored to the needs of the client and focuses on strengthening and rehabilitating the work team, training plan for employees, consisting of their improvement, focused on sales skills, expertise, conversation and approach to customers not only in mother tongue but also in foreign language, employee motivation and crisis management. Further trainings focus on attention as the main tool of guest care, methods of active telephoning and emailing, sales skills and their improvement, selection and search of employees, employee motivation.

The agency focuses on mystery emailing, mystery calling and mystery visit. Since eXpertz ltd. offers tailor-made services, it applies an individual approach to pricing. Prices published on the website range from $€ 29$ to $€ 69$ for mystery shopping and $€ 249$ for three-hour training. 
The advantage of eXpertz ltd. is its exclusive focus on tourism, professionalism, education and many years of experience of owners in tourism companies at home and abroad, their individual and partnership approach to the client.

Another agency is MysteryMan. During its operation, the agency performed hundreds of reviews of hotels and restaurants in Slovakia. It operates under the patronage of Pass Slovakia ltd. as a MysteryMan service provider. Until 2007, MysteryMan operated as an external company called Hotel for you ltd. As they claim on their website, they are the largest provider of mystery shopping services for hotels and restaurants in Slovakia and offer their services to top hotels and restaurants, thus helping them to constantly improve their services and effectively manage operations (www.mysteryman.sk).

The evaluation is based on a sophisticated model that uses a set of almost 200 criteria. These criteria came into existence as an intellectual property of the company on the basis of cooperation with hotel managers and international hotel companies at home and abroad. However, they are often supplemented during the evaluation based on the customer's requirements. The evaluation is followed by a training and counseling phase. The trainings focus mainly on practical exercises of the employee's behavior towards the customer, through simulated situations resulting from the evaluation visit. They are focused on the elimination of negative influences and the creation of positive contacts with customers.

On several occasions, the agency was responsible for evaluating hotels and restaurants during the Hotel of the Year and Restaurant of the Year competitions, which aim to provide an objective picture of the quality of the hotel and hospitality services. Facilities in the competition are evaluated using mystery shopping. The competition takes place in two rounds, the evaluation of the restaurant and bar is carried out in the second round. Every year, the Association of Hotels and Restaurants (ZHR SR) publishes the three most successful facilities in its category, which are evaluated in details through mystery shopping.

Interesting is specialized software called MysteryManager and it was created directly for MysteryMan. It makes it easier for employees and evaluators to work, as they process evaluations directly on the spot and can devote themselves fully to evaluation. Finally, the software enables statistical data processing that is more accurate and detailed.

Agency COMTESSA Consulting ltd. has been operating as a training and advisory agency for tourism in the Liptov and Tatras region since 2006. They focus their activities on lecturing tourism service providers, from top managers to employees who come into contact with customers. In addition to their educational activities, they also engage in mystery shopping. Mystery shopping is a secondary activity for the agency and focuses on 5 basic areas: reception, accommodation, dining, wellness \& spa, accessibility and how to provide information to tourists.

Mystery shopper is also in the case of Comtessa consulting ltd. a specially trained person who evaluates the appearance and readiness of the facility, welcoming the guest, seating, etiquette, dining or beverage menu, assortment of food and beverages, taking over the 
order, knowledge of food and beverage menu, recommendations of the server, approach, friendliness, willingness of service, dealing with special requirements, quality of food and beverages, complementary services, receipt issuance and payment (www.comtessa.sk).

The aim of COMTESSA Consulting ltd. is not only to point out the positives and negatives of employees or work processes in the company or tourism organizations. They help mainly in the elaboration of the company's strategy, marketing plan, SWOT analysis, through education and training they provide educated and prepared staff and thus try to eliminate potential threats and risks to achieve higher quality and prosperity of the facility.

After a short e-mail communication with the owner of the agency Comtessa consulting ltd. we found out that they had not yet performed mystery shopping in the hospitality facilities. They focus exclusively on the Liptov and Tatras region and a large part of their activities are devoted to trainings and workshops.

We decided to add the Market vision agency to our analysis, as it is one of the largest providers of mystery shopping in Slovakia. Since 2005, it has been the first agency in Slovakia to become a member of the international association MSPA (Mystery shopping providers association). The primary activity of the agency is not mystery shopping in a hospitality facilities or tourism, but in addition to mystery shopping in the automotive field. banking, construction, pharmacy, telecommunications, insurance, retail, luxury goods they are also engaged in hospitality mystery shopping. The agency has been operating on the market for 14 years and has already carried out more than 144,000 evaluations through mystery shopping. They have been working in the hospitality field for 3 years and have made more than 750 visits in hospitality facilities.

Like other mystery shopping agencies, Mystery vision provides an evaluation of service, its strengths and weaknesses, feedback on processes in the facility, recommendations for improving customer service and increasing sales. The agency has created the PLUS 1 concept, through which staff is taught to offer additional goods. Another activity that they implement is benchmarking or examining the behavior of a competitor as the competition seeks to retain a customer, compares the quality of service between stores and their evolution over time. If the company has more operation facilities, they try to balance the differences between the individual establishments. They also provide price analysis and information on current market prices (www.mysteryvision.sk).

They use the online application Spring not only for evaluation, registration of mystery shoppers but also for data collection. Thanks to this application, communication with mystery shoppers is easier and faster, where they have created their profile, sign up for an evaluation visit, download instructions and evaluation forms for individual visits and find out the reward. For companies, it is a quick source of feedback after the evaluation is carried out directly by the mystery shopper.

In addition to mystery shopping, the agency also specializes in the so-called Customer intelligence and Competitive intelligence. Through customer intelligence, they try to teach companies to know their customers, acquire new and retain old customers, involve them 
in decision-making and development, motivate employees and thus sell more. Competitive intelligence brings monitoring of competitors, their products and prices, an overview of news on the business market, etc.

\section{Hospitality facilities using mystery shopping}

In the references on the websites of mystery shopping agencies we have found out the hospitality facilities in which evaluations through mystery shopping took place. We have contacted 10 hospitality facilities where they used mystery shopping in order to find out what benefits they had examined after mystery shopping and how they would evaluate the work of mystery shopping agencies. We have received 3 positive responses from the hospitality facilities, which were willing to answer our questions. These were the Brewery Erb in Banská Štiavnica, the Restaurant Červený rak (restaurant, pub and wine bar) in Banská Bystrica and the Restaurant X in Banská Bystrica, where the F\&B manager willingly answered our questions, but the facility wishes to remain anonymous, so we do not mention its real name. We communicated with the Restaurant X and the Brewery Erb via e-mail, we met with the owner of the Restaurant Červený rak facility personally and we discussed the issues in more details.

By all three hospitality facilities the motivation for applying mystery shopping was to move to a higher level in the quality of services provided, increase customer satisfaction and ensure the constant concentration of staff by providing services. Companies recorded expected changes in the quality of provided services. However, the owner of Brewery Erb has seen only a short-term improvement in relaince to mystery shopping. She added that mystery shopping is only a small part of working with human resources. The owner of the Restaurant Červený rak stated that after the training of waiters, the number of satisfied customers increased, customers also noticed an increase in the quality of services, restaurant recorded increased sales and tips, an increase in upselling and rise of the company's reputation. The aim for evaluation through mystery shopping in the Restaurant Červený rak was to better customer service, which ultimately met their expectations.

When examining the benefits of mystery shopping, companies responded differently. While mystery shopping helped one company mainly in the area of improving the work of employees, in the other one it pointed out mainly the mistakes of management and did not notice changes in the work of employees. Restaurant X recorded a positive change in management and employees' behavior. They attribute the results to the personal decisions of management and staff who are seeking improvement in every matter, even the one which no longer seems to need any improvement. Employees responded to mystery shopping in the early stages with concern, but over time they generally accepted the assessment and perceived it as a chance for their personal and professional growth. The researched hospitality facilities recorded not only an increase in the number of customers but also an increase in their loyalty. However, the Brewery Erb did not attribute this increase to mystery shopping, but the number of their customers was constantly growing. 
The facilities perceive communication with the mystery shopping agency as a very professional. They provide services reliably, responsibly and professionally. The trainings were part of mystery shopping in the researched hospitality facilities. The companies perceive the training as practical, understandable, beneficial not only for the employees but also for the management. The owner and employees of the Brewery Erb appreciated the previous practical experience of the mystery shopping agency in the hospitality facilities, but they also said, that over the time, the training lost its effect and became monotonous in content and form.

The Restaurant Červený rak would be interested in using mystery shopping in the future as well, as they were satisfied with its results. Even though the work of the mystery shopping agency was evaluated positively, they think about contacting another agency and thus finding out a different view of the services providing in the hospitality facilities. Employees were informed about the evaluation before it was carried out but did not know the exact day and time. The owners of the Restaurant Červený rak appreciated that the owner of the mystery shopping agency came to the first evaluation, who found the main mistakes. Trained mystery shopper came for another visit. The evaluations were followed by training of employees and management. Finally, to determine whether the previous problems had been resolved and whether upselling had been successfully implemented, the mystery shopping agency carried out two further evaluations. Employees and management are still utilizing the training knowledge and number of satisfied customers is constantly increasing.

Restaurant X still realizes mystery shopping. Employees already had used to the evaluation and after multiple evaluations, perform their work with the greatest professionalism. But as the F\&B manager claims, there is always space for improvements, so they continue to do mystery shopping and training. Mystery shopping helps them to discover hidden mistakes that they can correct and thus improve the services in all aspects. They have a good relationship with the mystery shopping agency and consider their approach to be professional and practical. The trainings help them to eliminate the identified problems, especially in the work of management and employees.

\section{Conclusion}

The development of mystery shopping in Slovakia began a little later, around the year 2000. In this time the method was already well known abroad, however, in our country it was considered more like spying and catching employees by making mistakes. Many companies fight so far fought this opinion, but the method should not be used as a tool for restrictions or sanctions, but it should provide employees with feedback on performance and mistakes, which they may often not even realize. In addition to detecting employee mistakes it can also reveal problems in business processes.

In this paper we have analyzed the mystery shopping agencies that are engaged in the evaluation of services in the hospitality facilities in Slovakia. Tales \& tails is dedicated not only to the mystery shopping in hospitality facilities but is also dealing with catering and 
bartending courses. Agency expertz ltd. focuses exclusively on mystery shopping in tourism and the training they organize is based not only on the results of mystery shopping but especially on solution of the most common problems of tourism businesses. The main activity of the MysteryMan agency is the evaluation of accommodation facilities, but at the same time they also evaluate the hospitality department of the accommodation facility. Agency COMTESSA Consulting ltd. focuses mainly on training of hospitality facilities and tourism organizations in the Liptov region, but, in addition to training, they also engage in mystery shopping. The last analyzed agency was Market vision, which is the largest mystery shopping agency in Slovakia. It focuses on several service sectors, including tourism. We have found that in Slovakia there are not many agencies that deal with the evaluation of services using the mystery shopping method in the tourism companies. Except eXpertz ltd. no other agency is dealing exclusively with mystery shopping in tourism. In order to increase the sales of the agencies, they offer their services in several service sectors, thus expanding their corporate portfolios.

In the next part we have characterized the hospitality facilities using mystery shopping. We conducted structured interviews with the managers of the Brewery Erb in Banská Štiavnica, Restaurant Červený rak and Restaurant X, which wanted to remain anonymous. The hospitality facilities were satisfied with the results of mystery shopping and the subsequent trainings. They have seen an increase in their service quality and increased customer satisfaction. They want to continue to apply mystery shopping in the future. All three companies evaluate mystery shopping as a primary impulse for changes in the company but working to achieve success and satisfaction is a job especially for conscious management.

\section{Acknowledgement}

This paper has been supported by the grant VEGA 1/0368/20.

\section{References}

BAAROVÁ, E. and I. WAGNEROVÁ, 2008. Mystery shopping jako nástroj hodnocení pracovního výkonu [Mystery shopping as a work performance assessment tool]. Psychologie v ekonomické praxi, 43(1/2), p. 57-68. ISSN 0033-300X.

CHEN, R.J.C. and C.W. BARROWS, 2015. Developing a mystery shopping measure to operate a sustainable restaurant business: the power of integrating with corporate executive members. Sustainability, 7, p. 12279-12294. doi: 10.3390/su70912279.

COMTESSA.SK, 2020. COMTESSA Consulting Official Website. Online, available from http://comtessa.sk

ĎAĎO, J. and J. PETROVIČOVÁ, 2013. Marketing strategies. Banská Bystrica: Bratia Sabovci, 225 p. ISBN 978-80-557-0555-2.

EXPERTZ.SK, 2020. eXpertz Official Website. Online, available from http://expertz.sk 
GÚČIK, M. et al., 2009. Manažérstvo st'ažností v organizáciách služieb [Complaint management in the sector of services]. Banská Bystrica: Ekonomická fakulta UMB, 126 p. ISBN 978-80-8083-839-3.

JANKAL, R., and M. JANKALOVÁ, 2011. Mystery shopping - the tool of employee communication skills evaluation. Business: Theory and Practice, 12(1), p. 45-49. doi: 10.3846/btp.2011.05

MARKETVISION.SK, 2020. Market Vision Official Website. Online, available from http://marketvision.sk

MINGHETTI, V. and E. CELOTTO, 2014. Measuring quality of information services: Combining mystery shopping and customer satisfaction research to assess the performance of tourist offices. Jornal of Travel Research, 53, p. 565-580.

MORAVČÍKOVÁ, K., 2014. Mystery shopping - moderný nástroj na zvýšenie spokojnosti. In: Tredy v podnikání - mezinárodní vědecká konference, Plzeň. pp. 1-6 Online, available from <http://www.tvp.zcu.cz/cd/2014/PDF_sbornik/ moravcikova.pdf>

MYSTERYMAN.SK, 2020. MysteryMan Official Website. Online, available from http://mysteryman.sk

MSPA Europe, 2020. MSPA Europe Official Website. Online, available from http://www.mspa-eu.org

MYSTERY SHOPPING, 2020. Toptest. Online, available from <http://www.toptest.sk

PAROBOK, T., 2015. Mystery calling, Mystery e-mailing, Mystery shopping. Online, available from <http://www.perman.sk/index.php/sk/mystery-calling>.

TALESANDTAILS.SK, 2020. Talesandtails Official Website. Online, available from http://talesandtails.sk

\section{Contact address of the authors:}

doc. Ing. L'ubica Šebová, PhD., Department of Tourism, Faculty of Economics, Matej Bel University, Tajovského 10, 97590 Banská Bystrica, Slovakia, e-mail: lubica.sebova@umb.sk

Ing. Radka Marčeková, PhD., Department of Tourism, Faculty of Economics, Matej Bel University, Tajovského 10, 97590 Banská Bystrica, Slovakia, e-mail: radka.marcekova@umb.sk

Ing. Radim Dušek, Ph.D., Department of Tourism and Marketing, Faculty of Corporate Strategy, Institute of Technology and Business in České Budějovice, Nemanická 436/7, 370 10, Czech Republic, e-mail: dusek@mail.vstecb.cz 